\title{
Available For Evaluation Indicator
}

National Cancer Institute

\section{Source}

National Cancer Institute. Available For Evaluation Indicator. NCI Thesaurus. Code C93513.

Specifies whether or not an entity is accessible for assessment or testing. 